\title{
国際学会連合は哲学をどう変えるのか 哲学系諸学会国際連合(FISP)の課題と取り組み一
}

ル一カ・スカランティーノ

FISP 事務局長、ミラノ自由大学 [Università di Lingue e Comunicazione a Milano, IULM] 教授

佐々木健一

FISP 副会長、東京大学名誉教授、日本学術会議連携会員

聞き手 藤原聖子

日本学術会議第一部幹事

2017年 5 月 11 日 東京大学本郷キャンパスにて

本日は哲学系諸学会国際連合 (FISP) の事務 局長、ルーカ・スカランティーノ先生、副会長の 佐々木健一先生にお出でいただきました ${ }^{1}$ 。この ところ、多くの研究者は自分の大学の業務に忙殺 され、学会活動もローカルな学会で手一杯となり、 国際学会の動向などなかなか追えないという状況 です。あるいは、インターネット時代に、直接顔 を合わせる国際学会の存在意義は何なのかという ことも改めて問われているように思います。とこ ろが、そのような時代に、FISPの活動は哲学の あり方に実際に変化をもたらしているという話を 耳にしました。それについて両先生からお話を伺 いたいと思います。

最初に、FISPとは何か、何を目的とした組 織なのかということ、また、ご自身はどのように FISPの活動に関わってこられたかをお話しくださ いますか。

\section{哲学系諸学会国際連合(FISP) とは}

スカランティーノ○世界の主要な哲学会がほほ すべて加盟している国際組織です。会員は、日 本哲学会などのナショナルな学会とへーゲル． ゲゼルシャフトや国際サンタヤーナ協会などの 国際学会をあわせて、現在140学会ほどです。 会員学会は発足時から増え続けており、現在で も毎年 5 〜学会ずつ新規に加入しています。 地域バランスはこの15年でかなり改善されま した。私が事務局長に着任した2008年には会 員学会の約 $65 \%$ がヨーロッパの学会でしたが、 その後、アジアやアフリカの学会の加入が急速 に増加しました。

FISPの目的の一つは、研究者間の国際協力 を促進することです。ほとんどの大学間協定は 二者間（bilateral）のものですし、大規模な大 学が中心となっています。FISPの役割は、そ のようなネットワークからは外れているような 


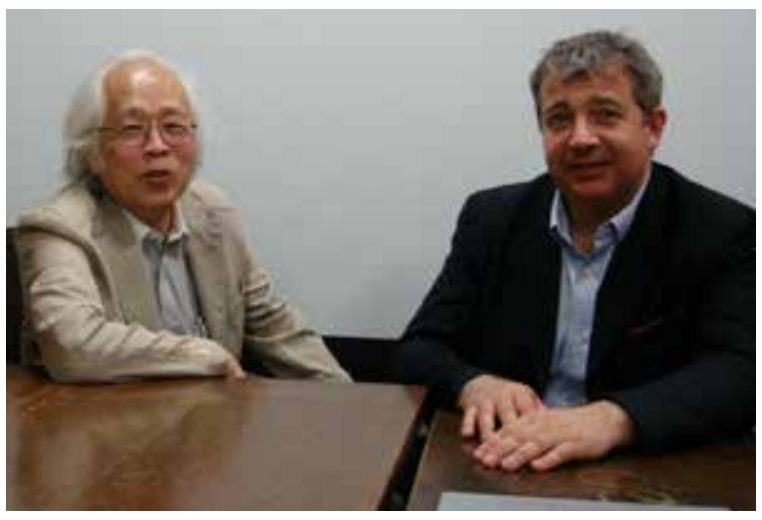

研究者たちをもつなぐことです。

これはネットワークの形成それ自体の他に、 哲学的反省の範囲を広げることを目的として います。私が学生のころ、「哲学の正典 canon」 に該当するのはほとんどが西洋哲学でした。ギ リシャ哲学から現代哲学に至るまでの哲学史を 総覧する 10 巻本があったのですが、アジア・ アフリカなど西洋以外の地域のことは、最後の 巻の残り数十ページになってやっと、「世界の 他地域の諸哲学」として出てくるだけでした。 FISPがやろうとしていることは、（哲学・思想 の）伝統間のコミュニケーションを促進するこ とです。自分の哲学伝統以外にも哲学伝統があ ることに気づかせること。ネットワークづく りを支援することです。私がここにいるのも、 FISP と『デイオゲネス Diogenes』2のつながり から日本の哲学を知るようになったためです。

よってFISPの目的は大きくは二つです。哲 学者間にネットワークを作ることと、多様な伝 統を取り入れることにより哲学の範囲を広げる
ことです。それをどのようにしてやるかですが、 毎年、運営委員会は会議を開催しています。ま た、世界各地で開かれる哲学関係の重要な研究 集会への委員たちの参加を奨励しています。

FISPの創設は、1948年です。この年はいく つもの主要な人文学の国際学会が始まった年で す。ユネスコが働きかけたのですが、その目的 は、第二次世界大戦後まもなく、研究者コミュ ニティ間の国際的ネット・ワーキングを再構築 することでした。冷戦下では、ユネスコの傘の 下で、西側と社会主義国側の研究者をひき会わ せることが必要でした。他の方法では交流のし ようがない研究者たちを結びつけたのです。つ まり、FISPは設立当初から研究者間の協働を促 進することを目的としていたのです。初期の事 務局長でもっとも著名なのは、ベルギーの哲学 者、カイム・ペレルマン（Chaïm Perelman）です。

佐々木○ちなみに日本の研究者がFISPに関わ るようになったのは、日本学術会議の哲学研 究連絡委員会（「哲研連」日本哲学会他、関連 6 学会による) が加盟してからです。

\section{交流が作りだす「開かれた哲学」}

スカランティーノ FISPの二つの目的は密接 に関係しています。今日、哲学にとり非常に重 要なのは、（哲学・思想の）伝統の多様性を認 
識することです。私自身は西洋哲学を専門とし てきましたが、西洋哲学は、それ自体はもちろ んすばらしい伝統ではあるのですが、哲学とい えば西洋哲学、という状態のままでは、もはや グローバル化した世界の人々に訴えかけること はできません ${ }^{3}$ 。

哲学史を顧みれば、西洋の哲学者は、決して 自国人のみを対象にして哲学を語ってきたわけ ではありません。ドイッやフランスやスペイン に限定することはなかったのです。今日、哲学 がインパクトを持つには一一持つべきだし、実 際、哲学にはそれだけの重要性があると思いま すが—、世界にもっと開かれなくてはいけま せん。自分の伝統を他に押しつけるのではなく、 他者の伝統、多様な伝統から学ぶということで す。日本の哲学、中国、インド、アフリカ、先 住民からも。宗教的伝統も含まれますね。それ らの伝統を理解し、そこから今日の世界にとっ て有意義な思想や概念を借りてくるというこ と。自分の伝統を異なる伝統の鏡を通して反省 するということ。西洋の哲学者にはこれがとて も必要になっています。

そのように哲学を開くことなしには、今、世 界で起こっていることを解読することはでき ません。私は最近、「公的な説得 public persuasion, public argument propaganda」について 研究しています。西洋哲学史では、公的な説得 への関心は古典古代には盛んでしたが、一度途 絶え、18〜19世紀にはそれが問題にされるこ とはほとんどありませんでした。しかし現在で は、公的言説において、感情的なインパクトが
言説に付与されるという面が新たに注目されて います。そのような新たな課題に取り組むには、 自分たちの伝統もふり返るべきですが、アジア の哲学から学ぶことが多いのです。西洋哲学は あまりに合理主義(rationalism)に偏ってしまっ たため、現代の文化的現象、象徵的現象や、コ ミュケーション現象は西洋哲学に固執したまま では理解することができません。

これを実現するには、本から学ぶという方法 ももちろんありますが、私の考えでは、他の地 域の研究者に直接会って交流することが必要で す。それなしには、他の伝統を理解するのはな かなか難しい。FISPはそういったさまざまな研 究者との交流の場として非常に有効です。毎年 の会議（運営委員会等）には40力国から40 50 人の委員が集まります。そのなかでどのよう に人に関わるかを学ぶことになります。さまざ まな文化の違いへの感受性が磨かれ、異なる歴 史に対する理解が促されます。その 50 人がこの 多国間（multilateral）の交流の体験を、それぞ れの哲学コミュニティに持ちかえるのです。

このところ、多くの国がこのFISPの定例の 年次委員会を進んで招聘しているのですが、そ れは、それに集まる研究者たちとの関係を直接 築くためです。世界の研究者とつながるという のはどうすればうまくいくのかを実際に試すと いうことです。私自身の場合でも、私がFISP に関わることが引き金となって、イタリアの哲 学会にこういった非西洋圈の哲学への感受性や 研究者との交流が広がるといったことを経験し ています。ですから、FISP事務局長としての 
仕事は、可能な限り哲学を開くということです ね。FISP と世界哲学会議 (World Congress of Philosophy, WCP：FISPの世界大会）に多様 な研究者が参加することを促進すること。それ によって、新しい考えだけでなく、多様な考え を取り入れることです。

\section{日本でも哲学といえば西洋哲学という見かたは 根強いのですが。}

スカランティーノのたしかに西洋の研究者のな かにも、「哲学を開く」ことに対しては批判が あります。哲学には境界（boundary）がある、 論理的な立論を欠くものはその境界のなかに入 らず、哲学とは言えないという批判です。たと えば『論語』は哲学ではない、とされるのです。 私自身はそういった意見には賛同しません。西 洋哲学史においても、境界はそのように厳密な ものではありません。『論語』を外すなら、ア ウグスティヌスも哲学とは言えなくなります。 しかし西洋の哲学者は誰もそうは言いません。 同様に、ソクラテス・モデルによる対話、論理 的立論のみを哲学として認めるなら、中世神秘 主義はすべて哲学から外れてしまいます。哲学 史上、撖密な方法は必ずしも常に要求されるわ けではなかったのです。

私の立場は、哲学のアイデンティティにこだ わるのはやめ、現代世界の文化を理解するの に、哲学はどう役立つかを考えようというもの です。そう考えるならば、哲学の境界は、明ら かに拡張します。しばらく前まではスーフィズ
ム（イスラムのなかの神秘主義的思想・実践） を哲学に入れる人はいませんでしたが、その 状況も変わりつつあります。杜維明（Tu Weiming: 中国の新儒家) がFISPの運営委員になっ たときにも、彼は哲学者ではないという批判が ありました。しかし、彼は哲学的に意味のある ものを書いているのであり、それが必要なこと ではないかという意見が通ったのです。哲学の 役割や目的を考えれば、現在は哲学として見な されていないが、かつては哲学とされていたも のも射程に入ってくるのです。

\section{その哲学の役割や目的について、 共通了解というものはあるのですか?}

スカランティーノ○それは哲学者の数ほどある かもしれませんね。私自身は、哲学を文化力 cultural forceの理論、知の構造の記述として とらえています。どのような知がどのような文 化形式に含まれているのか。どのような文化史 が特定の概念の背後にあるのかといったことが 関心事です。

ただし、目的を先に定めるより、「おもしろ いよ思うことの方が先行します。括しろい」 と思うものを哲学とみなすということです。た とえばダンテはふつう、哲学者ではなく詩人と されていますが、哲学にとってもとても重要な 人物です。科学哲学・分析哲学の分野でも、現 在では、伝統的な哲学の意味からすれば、「ど こが哲学なのか?」となる研究もよくあります。 しかし、それらは哲学ではない、とする理由は 
ないのです。私はオープンすぎるでしょうか、 佐々木先生?（笑）

\section{人文学の危機に対する FISPの活動}

佐々木○私が 2008 年にFISP の運営委員会に加 わってまず驚いたのは、何カ国もの大学の哲学 科から、学科が潰されそうだ、助けてほしいと いう要望が次々と送られてきたことです。ロシ ア哲学アカデミーに至っては、建物から追い出 されることになったという事態に陥っていまし た。ユネスコの政策も変わりました。哲学はも はや敬意を払われていません。そのような哲学 と人文学の危機的状況は今も続いています。

第二に驚いたのはFISPからの介入に効果が あったことです。FISPがそれらの大学に働き かけることにより哲学科が存続することになっ たのです。日本でも文部科学相の 6.8 通知に見 られるように、この問題は非常に深刻です。そ れに対しても日本学術会議からの働きかけ（幹 事会声明など）は一定の効果がありましたね。 FISPだけでなく国際哲学人文学会議 (CIPSH) の役員でもあり、CIPSH の雑誌『ディオゲネス』 の編集長でもあるスカランティーノ先生は、ど のようにこの状況を見ていらっしゃいますか。 FISPはどのような活動によりこれに取り組ん でいるでしょうか。

スカランティーノの重要な問題ですね。FISP の事務局長として、何年も支援のための手紙を 書いてきました。ロシア哲学アカデミーのケー
スはとても興味深いものでした。創設1923年 だか 24 年の会館をロシア政府が回収しょうと したのです。そこでFISPは国際的キャンペー ンを組織しました。数百人分の署名を 3 週間で 集め、送ったところ、ロシア哲学アカデミーは 追い出されず、建物ごと残ることになったので す。このようにFISPは世界の哲学者間の連帯 を強化することができるのです。

ここ数年はそういったSOSは減りましたね。 原因はわかりませんが。

もう一つの活動として、哲学者に対する政治 的な迫害に抗議することも行います。最近の例 ではハンガリーのケースがあります。FISPに は研究者コミュニティを守る役割があります。

\section{哲学・人文学の危機的状況は}

今後どうなるとお思いですか?

スカランティーノ○その状況も、世界を見る限 り、一概にそうとも言えないのですよ。人文学 が危機に瀕していない国もあります。中国や韓 国がそうです。中国は人文学にずいぶん投資し ています。少なくとも西洋の歴史を見る限り、 人文学はその国の拡張期に盛んになるという傾 向があります。ソフト・パワーと呼ぶ人もいま すが。

佐々木○ルイ14世の場合、戦争によりフラン スの国土を拡張するとともに、文化に投資しま した。文化の振興を通じて尊敬を集めたかった からです。 
スカランティーノ○そうです。尊敬され、認知 されるということを権力者は求めます。文化は その国に影響を及ぼす道具でもあります。中国 が今、人文学に投資しているのも驚くことでは ありません。

ですから世界どこでも同じように人文学が危 機というわけではないのです。FISPができる のは、その国のイメージやプレステージのため に、人文学が役割を果たしうるということに気 づかせることです。そのような影響力はヨー ロッパではすっかり失われました。人文学に対 する政策は、人文学は役に立たないという認識 に立っています。ですがそれは愚かです。フラ ンスではそれでも人文学の重要性はある程度認 知されていますが、スペインやイタリアでは、 危機とは言わないまでも、威信は失墜しました。

ですから今、私たちがなすべきなのは—こ の場合は研究者個々人が、ですが——人文学が いかに大事かを社会に伝えることです。国際学 会ができることは、世界中から研究者を集め、 学会開催地の当局に、あなた自身の文化は重要 なのですということを気づかせることです。

\section{文化政策の二面性}

佐々木○各国の文化政策はFISPの活動にとて も強い影響を及ぼしますね。たとえば世界哲学 会議（WCP）を開催するには費用がとてもか かります。現在まで、ほぼすべての世界哲学会 議はその国の政府によりサポートされていま す。とくに旧社会主義圈の東欧諸国は哲学だけ
でなく人文学の諸分野の世界会議を招致した がっています。文化面でのイメージ・アップを 図る文化政策のためです。しかしそれも今は難 しい状況にあるのではないでしょうか。次の世 界哲学会議は来年、北京で開かれるのですが、 中国のあと、そのような文化振興を行える国は 現れるでしょうか。

スカランティーノの私はそれについてはやや違 う見かたをしています。中国が世界哲学会議を 招致したのは、中国哲学を国際的な「哲学の正 典」として認めさせたいということがあるから です。中国哲学がドイツ哲学、フランス哲学と 同じくらい重要であると。正確に言うと、中国 哲学の専門家はこれまでもヨーロッパにも存在 するのですが、それでよしとせず、西洋哲学の 専門家であっても、中国哲学をも知っていると いうようにしたいということです。ほかにも同 じような考えを持つ国は存在するでしょう。日 本もそうなのではないですか。

世界会議の目的は、そのような個々の地域の 哲学コミュニティ・伝統・言語を、国際的な哲 学コミュニティの中心部にもちこむことです。 ですから、ヨーロッパのどこかで大会を開くの とは違うのです。中国人は単に人が来るからと いうことで世界会議に投資しているのではな く、開催することが、中国にとって知の歴史と いう観点から重要性があるためです。西洋の研 究者たちは中国哲学の豊かな伝統に向きあうべ きです。

私自身の経験をお話ししますと、世界会議を 
通して、私の研究方法も変化しました。自分に とって新しい概念を知る機会があるからです。 たとえば「㮆智・知恵wisdom」という言葉で す。先の世界会議で、中国人の学生から「皦智 についてどう思いますか」といきなり尋ねられ たのですが、そのときは答えにならないことし か言えませんでした。「わからないです。䜭智 という概念について私たちは研究したことがな いと思います。それは哲学の夕ームではないで すから」としか。しかし、彼の質問は私のなか でひっかかり、会議のあとも「彼は何を言いた かったのだろう」と考え続けました。それで気 づいたのですが、西洋の哲学にもかつて「辡智」 という概念・タームはあったのですね。しかし、 西洋の哲学者はそれを一度完全に破棄したので す。おそらくしかるべき理由があったのでしょ うが。とはいえ、西洋の哲学伝統の一部ではあっ たことは確かです。そこで私は、「撂智」がど のように西洋の伝統では扱われ、中国の伝統で は扱われたかを調べました。

このような哲学のやり方は、それまで私は経 験したことがないものでした。しかし、中国哲 学の伝統に接することで、自分の哲学を発展 させた人は私のほかに何人もいます。変化は、 ゆっくりとですが、確実に起きています。それ に中国の文化政策が結びついたのが次の世界哲 学会議です。哲学分野に限りませんが、中国の 大学は、世界からあらゆる研究者を招聘し、自 らもあらゆるところに赴き、大いに投資してい ます。それによって中国の文化が、実際、拡張 しています。もちろんその背後には、政治的な
意図があります。とはいえ、これは哲学・人文 学の観点からも意義あることなのです。ドイッ 観念論にもその政治的背景はありましたが、そ のためにヘーゲルやシェリングの哲学が学ぶに 值いしなくなるということはありません。スピ ノザもそうでしょう。もちろん政治性には注意 を払わなくてはいけませんが、それと哲学の受 容とが相いれないものであるとは私は考えませ ん。西洋の研究者は本当に他の哲学の伝統に自 らを開くべきなのです。過去にも西洋の哲学伝 統は、エジプト文化、インド文化、ムスリム文 化、ユダヤ文化などを吸収しながら発展してき ました。今、アジアの文化は受け入れられない というのは意味をなしません。

\section{日本の哲学との出会い}

佐々木○先生と日本の哲学の関係はどうでしょ うか。日本の哲学にご関心があってこの度来日 されたのですよね。

スカランティーノ○そのきっかけは佐々木先生 が巻頭論文を寄稿された、『ディオゲネス』の 日本哲学特集号（57巻 3 号 2010年）です。こ の特集のおかげで、私は日本の哲学について初 めて論文を読んだのですが、とても関心を持ち ました。昨年、私は非常にテクニカルな哲学、 知の理論 (theory of knowledge)、アメリカの プラグマティズムを研究していたのですが、そ の過程で気づいたのです。知の理論のなかのい くつかの重要な問題が、日本人の哲学者によっ 
て、興味深い形で扱われていたということに。 続いて、ちょうど和辻哲郎『風土』のフランス 語訳 (Augustin Berqueによる訳) が出ました。 それはすばらしい訳で、和辻の思想が明確に理 解でき、私の研究にとっても意義ある概念をい くつか見つけることができました。

ですから、私の日本哲学への興味は、日本文 化の専門家としての関心から来ているのではな く、哲学者としてのものです。京都学派は一 他の日本の哲学にも言えるかもしれませんが、 まだ学んでいないので—西洋の哲学者にとっ ても非常に重要な問題を扱ってきています。特 に知の理論に関してです。なぜ彼らの思想はす ばらしかったのか。20世紀のプラグマティズ ムでは、もっとも深い思索をした哲学者ですら、 京都学派ほど深遠ではありませんでした。なぜ でしょうか。京都学派は日本の伝統の哲学言語・ 方法を自分たちの哲学に取り入れたからではな いでしょうか。世界の研究者が共有する哲学言 説に、西洋の哲学者は持っていない思想や概念 をもたらしてくれるのです。西洋の哲学者は過 去に捨ててしまったような、忘れているような ものを。

たとえば西田幾多郎の「場所」の概念。西洋 哲学では聞いたことがないものですが、探せば、 過去には存在したのかもしれません。彼は自身 の禅の体験を合理化・理論化するために純粋経 験の概念に到達しました。西洋の伝統にも中世 の神秘主義など禅に比較できるものはあるので はないでしょうか。しかし近世以降の合理主義 化により、それは失われてしまったのです。
これは、政教分離や民主主義をもたらした、 西洋的合理主義を捨てろということではありま せん。他の文化を知ることで、忘却した自文化 の部分を回復すべきということです。京都学派 はまさにそのようなことをしたわけです。西洋 哲学に橋をかけることで、日本の哲学を発展さ せたのです。私の日本哲学への興味もそのよう にして生まれました。FISP と『ディオゲネス』 が「橋」になったのです。

日本の哲学には、環境に根ざした知の諸原理 があります。あるいは環境を人間間の連携が起 こる場としてとらえています。これは非常に重 要なことです。今日の文化間対話・文化的イ ンテグレーションに関わり、社会的インパク トを持つからです。というのも、文化間（intercultural)の相互関係を通しての統合の方向に行 かなければ、交流のない多文化 (multi-cultural) の状態になります。両者は全く異なる社会のモ デルです。

このように、異なる諸伝統に自らを開くこと は、今日の哲学にとって非常に重要なのです。 国際学会のようなグローバル・ネットワークは それに役立ちます。もちろん、哲学者にとって まず必要なのは、読み、重要なことについて書 くこと、そして学生を教育することであり、ネッ ト・ワーキングの方が先行しては転倒ですが。

\section{世界哲学会議への期待}

世界哲学会議を日本で開催する場合、 どのような成果が望めるでしょうか? 
佐々木○世界哲学会議が日本で開催されるとし たら、その意義は、すでに扮えになっていま すが、さまざまな国の哲学の伝統を集めること ですね。私自身、次の北京大会に非常に興味が あります。その全体テーマは「人間になるこ とを学ぶ Learning to Be Human（學以成人)」 です。非常に儒学的な概念で、実は、最初は おもしろいとは思えませんでした。ところが、 FISPの前回のブエノスアイレスでの運営委員 会で、いくつかの報告を聞いているうちに、「人 間」の概念、「人間になる」という概念が文化・ 時代によって非常に違うということに気ついた のです。そこから、「being human」というこ とをどのような意味で私たちは今日、理解して いるのかということに興味がわいてきました。 「人間」「人間になる・である」とは何かについ て再考することで、北京大会の射程を拡張でき ると思います。そうなれば、より大勢の参加が 見込めます。参加者が「人間」の意味を普通の 意味、あるいは単に儒学の人間概念にとどめる のでないならば、扫もしろくなるでしょう。

たとえば日本の伝統には、アリストテレス的 な「人間である」という概念はありません。ア リストテレスは「人間は理性的動物である」と 言いました。しかし日本には、人間は動物の一 部だという考えはないのです。仏教の世界観で は、人間と動物は別のものであり、人間である ことと動物であることは背反します。「人間」 という概念だけで哲学の問題ができます。

スカランティーノ○それはまさに哲学者が取り
組むべきことですね。「人間」とは何を指すか について、異なる観点から対立するところから 始めるということ。そこから何が出てくるか、 ですね。こういった展開は、40年前の世界哲 学会議ではありえませんでした。20年前です ら、周縁的でした。

つまるところ、哲学にとって肝心なのは、考 えるのにおもしろいことを見つけられるかどう かです。それがあるのならよい兆候です。たと えば儒学の立場を厳密な方法で擁護しょうと いったことならみなすぐに飽きるでしょうが、 異なる立場をつきあわせることで、会議の最後 に、これをもっと深めたいとか、これをもっと よく理解してみたいといった声が出れば、それ だけでもすばらしいことです。そのような変化 が、人間が考えるということなのです。これが あたりまえの方法であるべきです。

私が学生の頃は、ドイツ哲学以外を専門とす る人のことをからかったりしていました。非常 に偏狭頑迷な教育を受けていたからですね。こ の 30 年間で私が学んだのは、国際学会の一員 として外国を訪問することは、自分の哲学に とって非常に役立つということです。アジアの 研究者とヨーロッパの研究者では少し違うかも しれませんが。私の知る限りでは、アジア人の 研究者は、留学等で外国によく行くため、自然 に異なる伝統にさらされますが、ヨーロッパ人 はせいぜいヨーロッパ内でしか移動しないとい うことがありました。観光旅行は別として。で すから、ヨーロッパ人には、外に向かって開く ことがとても重要なのです。国際学会、ネット 
ワークはそのために有効です。

佐々木○国際学会に個人が参加することはとて も重要です。私は、若い頃は、世界会議に参加 する目的は新しい思想を学ぶことだと思ってい ました。今では、もっとも重要な意義は、世界 の研究者と知り合うことだと考えています。若 い人には世界会議に積極的に参加して、新たな コンタクトを作るようにと言いたいです。哲学 に関し、同じ関心を持つ人とだけでなく、全く 異なる見解を持つ人たちとも。

スカランティーノの実務的なことを言えば、北 京大会でも、学生の参加者に対して無料の宿泊 所を提供できないかと交涉している最中です。

\section{FISPのジェンダー・ポリシー}

佐々木○FISPは若手だけでなく男女共同参画 にも取り組んできましたね。

スカランティーノOFISPのジェンダー・ポリ シーは強力です。私も大いに支持しています。 たとえば、運営委員会内部のジェンダー・ダイ バーシティが広がるように、候補を推薦・応援 しています。女性哲学者の組織が世界会議でプ レゼンスを高めることを歓迎しています。

女性哲学者の組織は、FISP内にもあります し、アジアにもあります。国際女性哲学連合 (International Association of Women Philosophers, IAPh）がアジア支部を作ったのです。
大会を世界哲学会議北京大会の前日に開くこと になっています。

日本・韓国などの東アジア諸国の間にも女性 哲学者による興味深いネットワークがありま す。2011年に逝去された北川東子先生が作ら れたもので、今また活気が出てきており、今年、 ソウルで会議を開くそうです。私たちも応援し ています。

FISP内にはジェンダー問題委員会もあり、 委員長はアイスランドのトルゲスドティル (Sigridur Thorgeirsdóttir) 先生で、とても活 発に活動しています。北京大会では世界哲学会 議として初めてジェンダー研究を対象にした寄 付講座による講演（endowed lecture）を設け ることになっています。「シモーヌ・ド・ボーヴオ ワール講演」です。寄付講座講演は三〜四つの みですが、これはその一つなのです。ジュディ ス・バトラーが講演することになっています。 FISP内のジェンダー・バランスについては、 現在はまだ女性からの参画としてのみとらえら れていますが、これからは多様なジェンダー・ アイデンティティにも開かれるべきですね。 “man”を“human”に変えるなど、言葉について もジェンダー・ポリシーが浸透しています。

北京大会では参加者全員に渡すコングレス・ バッグに「女性哲学者カレンダー」を入れるこ とになっています。哲学史上のあらゆる地域 · 時代の女性哲学者の伝記や紹介を週ごとに入れ たものです。中国の開催者が予算をつけること を承諾しましたので、期待しています。

このようにFISPのジェンダー・ポリシーに 
関する取り組みは良好と評価しています。女性 の会長も、事務局長も、副会長も選ばれていま す。ジェンダー・バランスと文化バランスは、 役員選考の上でもっとも考慮すべきことの二つ となっています。

FISPは国際的哲学オリンピックも後援して います。今年はちょうど 2 週間後にロッテルダ ムで開催されます。私が主張しているのは、四 つの課題のなかに、少なくとも1名の女性哲学 者の文章からの引用を入れることです。文化的 多様性も考慮するよう働きかけています。この 間は和辻哲郎の引用を入れました。

\section{人文学総合雑誌『ディオゲネス』 のポリジ}

\section{国際哲学人文学会議（CIPSH）の雑誌}

『ディオゲネス』についてもご紹介いただけま すか。

スカランティーノ○私が編集長を務める『ディ オゲネス』にも、FISPに通じる方針があります。 『ディオゲネス』は Aクラスの国際ジャーナル であり、学術の国際水準を全て満たし、世界の 哲学・人文学者から尊敬されています。しかし、 この雑誌が他と違うのは、単に高い学術的クオ リティを保っているだけでなく、普通ならばそ のようなトップクラスのジャーナルには入らな いような論文を取り入れ、多様性をも高めてい ることです。つまり、よい考えや着眼点を多く 含んでいるのに、論文としての国際水準を意識
していないと見受けられる論文が投稿されてく ることがあります。引用のしかたや論証の手順 などに問題があるのです。アメリカのジャーナ ルに投稿したら、查読を通らず、そこで終わっ てしまうような論文です。しかし、『ディオゲ ネス』はそのような論文を、編集委員会内部で 丁寧に校正します。それを執筆者に戻し、その 上で出版するということをやっています。もち ろん、これは大変な作業です。しかしこれによっ て、『ディオゲネス』は単なるジャーナルでは なく、それ以上のものになっているのです。そ ういった多様な伝統を背景に持つ執筆者の論文 を、国際的な学術の最前線に持っていくのです。 また、この雑誌は、研究の「港」としても機 能しています。何らかのテーマで特集を組む場 合、まずゲスト・エディターを選び、その人の 研究者グループに寄稿してもらうのですが、さ らに編集委員会からも執筆者を何名か提案しま す。それによって、もとの研究者ネットワーク が拡大することになります。つまり、『ディオ ゲネス』は単に投稿されてきた論文を出版して いるだけでなく、国際的なネットワーク、研究 者のダイナミクスを作るのにも貢献しているの です。

2 年前にタイの女性哲学者、スワンナ・サタ ーアナンド (Suwanna Satha-Anand) 先生が「ア ジア哲学の倫理と感情」という特集テーマのプ ロポーザルを出されました。プロポーザルが受 理される場合は、そのことを証明する手紙を 送ってほしいという依頼がついていました。サ ターアナンド先生がその手紙を使い、タイの研 
究基金に対し、研究プロジェクトを申請したと ころ、首尾よく通ったのです。その基金をもと に、執筆者全員で会議も開き、論文を相互に検 討し、その上で投稿されました。その間、 1 年 半でしたか。これはやろうと思えば他の雑誌も できるのではないかと思います。雑誌が研究の ためのツールになるのです。編集委員長として、 こういった試みを援助するのは大変ではあるの ですが、非常にやりがいがあります。

\section{最後に、読者に向けて、哲学の今日的意義に ついて一言お願いいたします。}

スカランティーノ○哲学は今日、おもしろい特 徵をいろいろと持っているのですが、そのうち 二つあげるなら、

(1)人々に、開かれた方法で考えることを教える 能力。これはすぐに社会的インパクトを与える ものではありませんが、異なる人、異なる文化 の間で、開かれた形で、考えることができるよ うに教えるというのは哲学の重要な役割です。 (2)公的言説の分析。これは、短期的にはより社 会的効果があると思いますが、古来、哲学の役
割としてあるものです。昨年から話題の、「ポ スト・トゥルース」、「代替的事実（もう一つの 事実 alternative facts) 」 ${ }^{4}$ と言われるような新 しい言説状況が現在、生まれています。個人の 私的生活で経験することと、公共圈で見ること の間にギャップができているという事実がある のです。公共圈はこの新しい「偽」言説、通常 の理解での「真実」とは無関係のものを利用し ています。意味をなさないことを言い、それが 効力を発揮するという。そのような言説が私的 関係まで浸食しだしています。このような状況 では、哲学は、人々が公共圈で言説をどう巧妙 に作りあげるのかを分析するのに役立ちます。 政治的キャンペーンはどのように可能になるの かといったことです。意味をなさないことを言 いつつ、勝利者となる。なぜそれが可能なの か。こういった新しい形態の言説を解読するの が哲学です。というのも、哲学は、言説の論理 構造の見かたを人々に教え、論理と感情面の相 互作用を分析するということをやってきたから です。それは、今日の社会ではいっそう重要に なっていますね。

注

1 日本学術振興会の外国人招聘研究者プログラムにより、2017年春に来日（招聘者は、日本学術会議第一部・野家啓一教授）。日 本哲学への知見を深めることを目的とされた。

2 後出のように、スカランティーノ氏が編集長を務める、国際哲学人文学会議(CIPSH)のフラグシップ・ジャーナル。哲学者ロジェ・ カイヨワにより1953年に創刊された。言うまでもなく、ディオゲネスは「樽の中の哲人」として知られる古代ギリシャの哲学者。

3 日本では、西洋哲学の他に中国哲学、インド哲学なども当然のように存在するという伝統がある。2016年3月に日本学術会議 の「報告」として公表した、「哲学分野」の「大学教育の分野別質保証のための教育課程編成上の参照基準」では、日本の大学 で教えられている「哲学」を8分野に分け、それぞれの歴史的成立過程について説明しているので、ぜひ参照されたい。 http://www.scj.go.jp/ja/info/kohyo/pdf/kohyo-23-h160323.pdf

それに対し、ヨーロッパでは、哲学といえばそれは西洋哲学を指すことが自明視されてきたというのはスカランティーノ氏の発 言のとおりである。

4 2016年のイギリス・EU離脱の是非をめぐる国民投票やアメリカの大統領選挙において、多数の偽ニュースがインターネット上 に流布し、投票行動を左右した可能性が指摘されている。そのような事実を軽視する社会の風潮を示す表現。 